\title{
Immuni response of the pig to respiratory diseases
}

\author{
3. ('HARLEY \\ Laboratoive de Pathologie Porcine, I. N.R. A., \\ i8850) Thiverval-Grignon.
}

In the respiratory tract, the major immunoglobulin is I $\mathrm{A} \backslash$. Repeated lung washings on living pigs demonstrated the presence of alveolar macrophages and lymphocytes.

During an experimental swine influenza infection, we observed a systemic cell-mediated immune response, followed by an independent increase of local ( $\mathrm{IGG}$ and $\mathrm{I} g \mathrm{~A}$ ) and systemic antibodies. Whereas serum antibodies persisted, local antibodies were only detectable cluring a short period.

Colostral immunity is able to reduce clinical symptoms of the disease, however inhibition of viral replication and release requires efficient local immunity.

\section{Classical swine fever. Duration of the immunity obtained in sows by raecination with the Thicerval strain}

\author{
M. LAUNAIS, J-M. AYNAUD \\ Laboratoise Cogla, \\ Institut Biologique de Libourne, \\ 13.P. 126 , \\ 33500 Libourne \\ Laboratoive de Pathologie Porcine, I. N. R. A., \\ 78850 Thiverval-Grignon
}

Study of the kinetics of serum antibodies neutralizing the swine fever virus enabled us to determine the characteristics of the immunity obtained after one only injection of a live vaccine (Thiverval strain) to gilts.

The rapidly obtained immunity reached a high level (index $<5$ ) and remained for at least 39 months at that level, thus providing an efficient protection to the gilts during their whole reproductive life. 